\title{
A network society, social media, migration and mission
}

\section{C.J.P. Niemandt ${ }^{1}$}

\section{Abstract}

Human mobility and migration are closely associated with and reciprocally influenced by globalisation. Add the relentless connectivity facilitated by the proliferation of mobile communication and the emergence of social media to this mixture, and an emerging new 'glocal' culture is evident. People are not only migrating to new localities and territories, but simultaneously into a new culture. We are witnessing the greatest mass migration in the history of humanity - from the real to the virtual world. It is a shift from shared space to shared interest.

The metaphor of a river in flood has been used to describe the fact that migrant communities are a point of convergence of some of the biggest challenges facing the church and society at large: globalisation, hyperdiversity, interconnectedness, a Google culture and postmodern tribalism. Culture flows like a river and the church functions as a bridge connecting humans striving to make sense of life and Scripture as well as the tradition transmitted over the centuries. Some of the missional challenges will be to incarnate the gospel in this emerging culture. This study was positioned at the convergence of two important processes - the rise of the network society (especially social media) and migration. It took up two of the challenges posed at Edinburgh 2010, namely to "fruitfully" integrate the role of media in modern society into overall missiological thinking, and to think about the "call for a structural reform of the church" to grapple with the challenges of migration.

The network society represents a profound social transformation. New technologies deliver connectedness in the palms of our hands and social media serve as an expression of the passion for connection, community and knowing others and being known by others.

This research is a theoretical and missiological reflection on the role and importance of social media such as Facebook in migrant communities. It investigated issues such as:

- contextualisation and inculturation in a Google culture;

- the foundational role of relationships in a network society and migrant culture;

- the ability of social media to facilitate connection to the multiple cultural and religious belongings of migrants;

- the role of social media to help migrants to find meaning through shared, self generated experiences;

- the role of social media in facilitating hospitality to the stranger.

Keywords Migration, Mobile communication, Social media, Google culture, Network society, Contextualisation, Inculturation, Theology of dialogue

1 Prof Cornelius J.P. (Nelus) Niemandt is at the Department of Science of Religion and Missiology, University of Pretoria. He can be contacted at nelus@pixie.co.za Postal address:75 Elveram Street, Lynnwood Glen, Pretoria, 0081, South Africa 


\section{Introduction}

We are the first generation to live in a new world, a global cosmopolitan society, shaped by globalisation. Anthony Giddens (2002:19) says that "globalisation is not incidental to our lives today. It is a shift in our very life circumstances. It is the way we now live." Globalisation is a complex set of processes that flow together and are creating and shaping a new world. We need to shape new institutions, or reconstruct the ones we have, including the church and its understanding of mission, to face up to the challenges posed by this new world. We thus need a globalising theology that takes these challenges seriously and in which Christian communities throughout the world participate (Netland 2006:30).

This new era has been constituted by much more than just globalisation: human mobility and migration are closely associated with, and reciprocally influenced by, globalisation. The world's population is experiencing rapid growth and people are constantly on the move. Mobility and migration are becoming defining characteristics of this era are among the great global realities of this new order. In 1998 more than 120 million people lived in countries other than those in which they were born. More than 175 million people are on the move worldwide (Balia and Kim 2010:43). This represents a shift from rural to urban, from poor countries to rich cities and from one nation to another (Miranda-Feliciano 2009:240). It is a present-day global diaspora.

When we reflect on human migration, we must take cognisance of the fact that migration takes place mostly to cities - "The world is in the cities. The cities are the world" (Miranda-Feliciano 2009:240). Christianity has always made its presence felt in cities, and the close relationship between human migration and urbanisation focuses on the importance of cities as a legitimate context for authentic religious experiences. Edinburgh 2010 acknowledged the importance of urban contexts for the future of the church (Balia and Kim 2010:43; Kim and Anderson 2011:168).

Globalisation, human mobility and migration are already building up to form a perfect storm that will leave nothing unchanged. Add the "relentless connectivity" (Castells et al. 2007:loc.4894) facilitated by the proliferation of mobile communication and the emergence of social media, and it becomes evident that a new 'glocal' culture is emerging. Glocal signifies the dynamic interrelatedness of the global and local (See also Van Engen 2006:157.). Individualisation and personalisation are proceeding apace with globalisation. People are not only migrating to new localities and territories, but simultaneously into a new culture where even the experience of time and space is being transcended - a change from a Gutenberg to a Google culture (Sweet 2012:3). Marshall McLuhan in his book The Gutenberg Galaxy (1962) famously described the end of the events spawned by the invention of the printing press as the end of the "Gutenberg era". He 
showed how communication technology affected cognitive organisation and thus social organisation (1962:41). Gutenberg culture flowed into Google culture. This terminology refers to more than people using the Google website to search other websites. The term alludes to the digitised, globalised and connected world and the multitude of relational networks enabled by social media. "Googlers have rewritten the rules of forming networks, connections, and relationships. In the hands of Googlers, technology has been bent to the purposes of core human longings: knowing, being known, belonging, perception" (Sweet 2011:loc.1284-1286). Jonathan Gottschall (2012:194-195) makes the point that we are witnessing the greatest mass migration in the history of humanity. People are moving en masse from the real to the virtual world, and although bodies will always be marooned on earth, human attention is gradually draining into the virtual world.

If culture is defined as the more or less integrated system of ideas, feelings and values and their associated patterns of behavior and products shared by a group of people who organise and regulate what they think, feel and do (Tennent 2010:loc.1849-50), it is evident that the new Google culture will play an important role in understanding the inculturation of the Christian faith in individual and communal identities.

This digital, global, connected culture represents a new paradigm within which people are defining themselves and understanding themselves in completely new ways; it affects the way we see, what we hear, how we interact with the world around us and how we communicate with others (Challies 2011:loc.87,91). The digital revolution is global, reaching to the farthest corners of the earth. It is a paradigm shift that is consciously and subconsciously transforming commonly accepted habits, notions and patterns of thought in its wake (Balia and Kim 2010:67).

Perhaps a metaphor might help us to grasp the relentless nature of the changes facing the church in its mission and of the pivotal role of migrant communities to assist us in discerning where the Spirit is working, so that the church can join in with God's mission. The metaphor of a river in flood comes to mind: migrant communities are a point of convergence of some of the biggest challenges facing the church and society at large such as globalisation, hyperdiversity, interconnectedness, a Google culture and postmodern tribalism. Thomas Friedman $(2005: 200)$ uses the term "triple convergence" in his influential The world is flat to describe the converging influences that are creating a new flat, globalised world, while Rex Miller speaks of a massive convergence of infrastructures (Miller 2004:6). I propose that migrant communities can be described as points of "multiple convergence." The metaphor can be expanded to enhance our understanding of the role of the church and our understanding of mission. Culture flows like a river and the church functions as a bridge connecting, on the one riverbank the humans striving to make sense of life and, on the other bank, 
Scripture and the traditions transmitted over the centuries (Dingemans 2005:241). Some of the primary missional challenges will be to incarnate the gospel in this creative, participatory and relational culture (Pagitt 2010:loc.416) and extend hospitality to migrants. This study is thus positioned at the convergence of two particularly important processes - the rise of the network society (especially social media) and migration. This takes up at least two of the challenges posed at Edinburgh 2010 (Balia and Kim 2010:139), namely to "fruitfully" integrate the role of media in modern society into overall missiological thinking, and to think about the "call for a structural reform of the church" to grapple with the challenges of migration (Balia and Kim 2010:135).

The African context reflects the global context. The mass displacement of peoples, globalisation and its ambiguities, human mobility and migration together with its interface with mission, unjust economic systems as part of the shadow sides of globalisation taking their toll on the poorest of the poor on the face of the earth -these global characteristics are all too evident in Africa (Unchem 2009:1). In the pilot case study, it will be shown that this cultural flood has also shifted context and paradigms in South Africa, changing the cultural face of the country. The use of digital social media particularly underlines the role of new technologies in the inculturation of the gospel in this convergence.

\section{The network society}

One of the characteristics of the new global culture is the network society. Networks as such are not new - they are a well-known form of social organisation. What is new are the microelectronics-based networking technologies that provide an old form of social organisation with new capabilities. Thus, the "new" network society is described by the eminent sociologist Manuel Castells (Castells et al. 2007) as a society whose social structure and social practices are organised around microelectronics-based networks of information and communication. The network society represents a profound social transformation because of the different phenomena related to the social, political, economic and cultural changes caused by the spread of networked, digital information and communications technologies. New technologies, and especially mobile telephony, deliver connectedness in the palms of our hands and social media serve as an expression of the passion for connection, community and knowing others, and being known by others.

One of the most important characteristics of the network society is the fact that mobile telephony has moved from being the technology of a privileged few to mainstream technology (Castells et al. 2007:loc.214). Globally, there has been an explosion of wireless communication and especially mobile phones, to such an extent that the presence and social 
influence of these technologies have given birth to the network society - a society where social structures have been enhanced and radically influenced by these technologies. "The fact that most of the world's population is entering the electronic communication age in a wireless mode has social and cultural consequences, the importance of which we are only beginning to perceive" (Castells et al. 2007:loc.835).

One of the fundamental changes in this emergence of new social structures is that the importance of "place" is secondary to the importance of "flows". It is the flows of information, images and capital that increasingly shape society. Locality, place and territory are still significant, but only as another layer of the complex shape of society.

"The Internet is both an example of network society and a metaphor for understanding it. From one perspective the Internet has no centre. There is no one 'place' where choices are controlled. Everywhere is linked to everywhere else. Each person chooses his or her own route, with a search engine as the only pilot. Networks of relationships are formed in chat rooms around mutual interests. Friendships are maintained electronically."

(Archbishops' Council 2004:5)

In this new world order technology has been utilised to serve the purposes of core human longings: knowing, being known and belonging (Sweet 2011:loc.1284-1286). Since shared interests rather than shared space now define community (Challies 2011:loc.1781-1782), the role of social media in a network society and the formation of community must be understood and appreciated. What is different about this situation is that digital communities bring people together apart from their bodies - "We now consider community what was previously mere communication" (Challies 2011:loc.1768-1769). It is a world of hyperconnectivity and multimodal communication from anywhere to anywhere (Castells et al. 2007:loc.99). The network society is a hyper-social society, not a society of isolation. There are different opinions on the issue of face-to-face interaction and the impact of the network society. Some are skeptical about the ability of the network society to create meaningful connection, others are much more positive. It is significant to note that some observers claim that internet users are more social and have more friends, and are more socially active than non-users. Penn and Zalesne (2007:253-256) state that the social uses of technology far outstrips the antisocial, individualistic purposes technology used to serve. In the words of Sweet (2012:93): "Google Search doesn't just bring facts faster; it brings friends closer." The case study seems to vindicate these observations.

The Atlas of Global Christianity (1910-2010) recognises the fact that global Christianity exists within a social and economic context and acknowledges the human need for connection and belonging, and it accepts 
the contribution of the internet in achieving this (Johnson and Ross 2009:2). Social researchers also note that religion has found a place for mobile communication technology (Castells et al. 2007:loc.1554).

\section{Contextualisation and inculturation in a Google culture}

Human context is always cultural. "To be human is to be cultural" (Koyama 2010:46). The new globalised, hyper-diverse, interconnected Google world is creating a new culture, changing macro systems such as the world financial order, but also influencing personal aspects of humanity and religion. The digital world alters the very texture of our lives. "Technology, as it is practiced, is society, and it embodies society" (Castells et al. 2007:loc.1589). We are witnessing the birth of a Google generation - a digitised, globalised group that spends much of its life getting to know one another in a virtual world (Sweet 2012:3). The Google culture does what all cultural changes do it shapes our behavior and how we express our beliefs.

Andrew Walls (2009:49) states that the theological agenda is culturally induced; culture necessarily sets new tasks for theology. One can not engage with the gospel independent of culture (Shenk 2006:9). The convergence of globalisation, migration, the emergence of a network society and a Google culture pose profound questions on concepts such as inculturation and contextualisation. Tennent's definition is very helpful: "formulating, presenting and practicing the Christian faith in such a way that is relevant to the cultural context of the target group in terms of conceptualization, expression and application; yet maintaining theological coherence, biblical integrity and theoretical consistency" (Tennent 2010:loc.3898-3900). The important and defining role of communication in global Google culture highlights the fact that contextualisation is about effectively communicating the gospel, not simply effective communication in some generic sense. Inculturation and contextualisation are an integral part of communicating the gospel.

How can the Gospel be contextualised and inculturated in a Google culture? What creative response can assist the church in mission to respond to this changing context? A theology of dialogue, described by Bevans and Schroeder (2011:21-22) as dialogue that leads to communication, and attitude of friendship and respect and a practice of openness, may be the clue. The term dialogue is used to indicate an attitude of respect and friendship, which permeates all those activities constituting the evangelising mission of the church. Dialogue is "a style of living in relationship with neighbors" (Bevans and Schroeder 2011:22). It proceeds with the expectation of meeting God who has preceded us and has been relating to people. The proliferation of social networks such as Twitter and Facebook underscores the predisposition towards dialogue of this culture. The foundational role of communication and relationships in both a network 
society as well as in migrant culture makes this dialogical approach to contextualisation and inculturation even more relevant.

\section{The foundational role of relationships in a network society and migrant culture}

Margaret Wheatly, in her book on leadership and the new science, acknowledged the primacy of relationships in physic and said that we are beginning to rethink our major issues, including societal issues, in more relational terms (1999:14). Contextualisation and inculturation in this new culture occur in the context of relationships. Relationships are the embodiment of the gospel in communities. The term used in the Edinburgh 2010 study process is especially useful - diapraxis (Balia and Kim 2010:47). Diapraxis entails bringing together dialogue and praxis. It is dialogue that develops relationships across the barriers of faith, race, gender and culture. Diapraxis has a strong focus on joining in with the Spirit by joining in with others. Sweet states that relationships have become the most valuable and important form of cultural capital in our globalised world: "The social-networking generation is sold out to relationships" (Sweet 2011:loc.811-812).

Relationships are one of the defining characteristics of the new culture. Digital technology provided the means to organise and develop cohesive communities across, between and around current organisations (Miller 2004:83). It allows the re-emergence of intentional communities that reconstruct the components of an extended family - including the church. In terms of migrant communities representing a new kind of convergence, the same predisposition towards relationships can be identified - the very nature of being a minority in a situation of liminality enhances the foundational role of relationships. (The pilot study conducted as part of this research affirmed the importance of relationships in the particular community.)

Edinburgh 2010 describes the situation of many immigrant Christian congregations as "vulnerable", and that vulnerability can also be experienced by Christians in minority situations (Balia and Kim 2010:194). Migrant culture can be described as a community in liminality. The anthropologist Victor Turner studied the structure of rites of passage and expanded on theories on the liminal phase. Turner describes liminality as the transitional state between two phases or stages in life, when individuals no longer belong to the society that they were previously a part of and are not yet reincorporated into the new or prospective society. Liminality is an in-between, marginal state in relation to the surrounding society, an ambiguous period characterised by humility, seclusion, tests, sexual ambiguity and communitas (see Burger 1995:25, Hirsch 2006:220). Liminal individuals are "neither here nor there; they are betwixt and between the 
positions assigned and arrayed by law, custom, convention, and ceremony" (Turner 1969: 95).

For Turner, liminality is one of the three cultural manifestations of communitas - it is one of the most visible expressions of anti-structure in society. Yet even as it is the antithesis of structure, dissolving structure and being perceived as dangerous by those in charge of maintaining structure, it is also the source of structure. Just as chaos is the source of order, liminality represents the unlimited possibilities from which social structure emerges. While in the liminal state, human beings are stripped of anything that might differentiate them from their fellow human beings - they are in between the social structure, temporarily fallen through the cracks, so to speak, and it is in these cracks, in the interstices of social structure, that they are most aware of themselves (La Shure 2005).

The liminal period creates a rudimentarily structured society, a communitas. Communitas differs from societas. Societas represents a stage where a society is well structured, where the participants share feelings of wellbeing, security and growth. Communitas arises in situations where individuals are driven to find each other through the common experience of ordeal, humbling, transition and marginalisation. Communitas is characterised by uncertainty, transition and a lack of structure. Turner (1967:93) describes it as anti-structure. It involves intense feelings of social togetherness and belonging, adventure and movement, and constitutes a unique experience of togetherness. Communitas is an intense community spirit, the feeling of great social equality, solidarity and togetherness. It is a time filled with significance, meaning and relationships (Burger 1995:26).

Liminality, being part and parcel of displaced migrant communities, combined with the ability of a network society to organise social structures and practices around microelectronics-based networks of communication, creates a powerful convergence that is significant in migrant communities. Castells et al. (2007:loc.1574) say that mobile telephony is a critical tool for immigrant populations.

Contextualisation and inculturation, understood from the perspective of diapraxis, acknowledge and build on the importance of relationships in migrant communities and embrace the opportunity presented by the relational nature of the network society. Relationships, communion and dialogue are the ultimate goal of all existence (Bevans and Schroeder 2011:26).

\section{The ability of social media to facilitate connection to the multiple cultural and religious belongings of migrants}

One of the characteristics of the network society is the emergence and growing influence of social media. Social media refers to many forms of interactive digital communication. Kaplan and Haenlein (2010:59) define it 
as "a group of Internet-based applications that build on the ideological and technological foundations of Web 2.0 and that allow the creation and exchange of user-generated content." It is a form of horizontal communication where content is created and commented on by "amateurs, by the crowds of users rather than a few professionals" (Challies 2011:loc.1117). Social media are a form of self-directed mass communication that allows people to communicate with each other without going through the channels set up by the institutions of society for socialised communication.

"Social media encompasses a broad range of activities, platforms, and technologies all with a common theme: the ability to rapidly publish to the Web and to communicate with an audience. These tools and audiences take many different forms, ranging from short, 140-character Tweets on Twitter, video blogs and audio podcasts, to Internet forums, Facebook Groups and Pages, review sites and photosharing services. When you create, comment, converse, rate, review or publish, you're participating in social media."

(Brown 2011:loc.16)

"Social media is a term that means "community" (Sweet 2012:146). Social media, such as Facebook, have changed our social universe. A few brief facts illustrate the reach, power and influence of social networks:

- One in every nine people on earth is on Facebook;

- People spend 700 billion minutes per month on Facebook;

- Each Facebook user spends on average 15 hours and 33 minutes a month on the site;

- More than 250 million people access Facebook through their mobile devices;

- More than 2.5 million websites have integrated with Facebook;

- 30 billion pieces of content are shared on Facebook each month.

(Bullas 2011)

No wonder enthusiastic observers describe the rise of social media as a seismic event that is changing everything. Eric Harr (2012) says: "Social media is everywhere in the news. It pervades every area of our lives... Social media hasn't changed one thing. It has changed everything." The role of digital media, especially social media, as an agent of change amounts to nothing less than a social revolution.

From this brief discussion, it is clear that social media fit the description of advanced electronic media formulated in the Edinburgh 2010 study process 
(Balia and Kim 2010:44) as new forms of "co-presence and interaction", and thus a new challenge and opportunity for mission. Many observers doubt the ability of digital media and the virtual world to create significant community. Challies (2011:loc.1897-1898), to mention but one, says that the online church is a concession in the face of unavoidable circumstances. It is never a replacement for the real thing. Yet Gottschall (2012:196) is convinced that the virtual world is in important ways more authentically human than the real world: "It gives us back community, a feeling of competence, and a sense of being an important person whom people depend on".

Digital culture facilitates the emergence of the convergence church (Miller 2004:76). Social media can facilitate connection to the multiple cultural and religious belongings of migrants and can assist in the inculturation process of diapraxis. The co-presence and interaction made possible by social media seem to be very well suited to the process of "othering" - the risky, demanding, dynamic process of relating to one who is not us (Balia and Kim 2010:46). In the case study conducted as part of this research, social media played a surprisingly important role in relationships and community building.

I have already referred to the importance of communitas in migrant communities. This leads to a renewed appreciation of the "other", a new equality and openness towards each other. Social media enhance this equality and openness. It is a form of horizontal communication where everybody is equal. Sweet remarks that "the Google revolution is democratizing religion by taking it out of the hands of the gatekeepers and enabling more open-source, self-organizing connections with God" (Sweet 2012:111). The case study underlined the fact that there is an openness to the "other", enhanced by the availability of social media.

\section{The role of social media in helping migrants to find meaning through shared, self-generated experiences}

The issue of migration is central to the church's missionary activity (Bevans and Schroeder 2011:136). Social media facilitate multiple connections for migrant communities that strengthen cultural and religious belongings and identity. All identity comes from relationship. Social media can play an important role in creating identity and meaning through shared experiences and by enabling relationships and connectedness. Friedman (2005:478) observes that digital media enable uploading. Uploading is the realisation of the collaborative power of individuals and communities (Friedman 2005:95) to create content around their own self-generated experiences and to be producers of culture. This ability to upload and create one's own content is a very powerful force for the preservation and enhancement of cultural autonomy and particularity. It enables the globalisation of the local. Social media are participatory and relational by their very design, and thus enhance 
the ability of communities to find meaning and identity. "Online relationships may be a different kind of real, but they can be as veritable and valuable in their own way as off-screen, on-site relationships" (Sweet 2012:166). Miller (2004:106) says that the digital era allows individuals to design separate identities for themselves for different roles and contexts. In a digital culture identity comes from the multitude of interactions around the globe, allowing people to be members of numerous communities.

It comes as no surprise that the observations of Castells et al. (2007:loc.1574) showed that the technology of the network society has enabled migrant and displaced populations to stay close to their cultural origins. The cases study underlined the important role of social media in migrant communities in this regard.

\section{The role of social media in facilitating hospitality to the stranger}

The importance of dialogue and especially diapraxis as a way to contextualise the gospel in the convergence of Google culture and migrant communities has been noted, as well as the potential of social networks to create and enhance community and an appreciation for the "other". Social media open up exciting possibilities to express one of the most basic missional expressions of "othering"- hospitality or welcoming the stranger (Keifert 1992:7). As Amy Oden (2008:11) says, gospel hospitality has always been at the heart of Christian life. A missionary church is characterised by welcoming the stranger and hospitality (Archbishops' Council 2004:82). The practice of inclusion is at the heart of the kingdom and an ultimate expression of missional dialogue. It is a readiness to welcome, to enter another's world and also to be vulnerable. Edinburgh 2010 called on Christians in nations which have immigrant communities to bear counter-cultural witness to the love of Christ in deed and word, by obeying the extensive biblical commands to love the stranger (Kim and Anderson 2011:454). Social media, with its focus on creating community and ability to assist people to share life, pain and joy, present a wonderful opportunity to extend hospitality. It can connect strangers and serve as an entry point to make face-to-face interaction possible.

Diapraxis, facilitated by social networks, can help to form community-orientated dialogue that assists the process where strangers meet, where people in liminality can connect to each other and create community. Social media helps the church to navigate in a society where the importance of place and locality becomes secondary to the importance of "flows" - the flows and connections of information, images and capital that increasingly shape society. These "flows" create interesting opportunities to meet strangers and to connect to each other, and social 
media seem to present an opportunity to facilitate new forms of hospitality to the stranger.

\section{Case study}

A pilot case study has been conducted in Pretoria in South Africa (in May 2012) amongst four French-speaking migrant churches to serve as a source of information and reflection on the use and role of social media. ${ }^{2}$ The results were used to interpret and evaluate the theoretical and missiological reflections presented above.

Some information on the use of social media in South Africa in 2012 might serve as valuable background:

- There are 4841380 Facebook users (9\% of the population, but $91,35 \%$ of the online population), with the largest age group 18-24. The average Facebook user spends 700 minutes a month on Facebook. $50 \%$ of Facebook users access it via mobile phones;

- There are 1100000 Twitter users and about 470000 Tweets per month. Karanja (2012) found that this increased to 5000000 in three months in 2011;

- Mxit is the largest network in South Africa and has 10000000 users and is "teenage dominated";

- There are 31 million internet-capable phones in South Africa and by 2020 South Africa will have 20 million internet users.

(Chatterbox 2012)

The results of the case study might serve as a valuable tool and as a source of information and reflection on the use of social media to be able to interpret the theoretical and missiological reflections presented above.

\section{Background on the respondents}

All of the respondents have a mobile phone and $86 \%$ have access to the internet. Although the sample (19 qualitative interviews) may be small, these figures indicate a significant variation - and much higher internet access - in terms of the broad South African population, and indicates a predisposition of members of migrant churches to use the internet - perhaps because it is such a valuable tool to keep contact with their countries of origin.

\begin{tabular}{llll} 
Matric & \multicolumn{2}{c}{ Level of education } & \\
$39 \%$ & Undergraduate & Graduate & Post-graduate \\
& $22 \%$ & $33 \%$ & $6 \%$
\end{tabular}

2 The interviews were conducted in French by the Rev. Athas Mpinga from UNISA and the results were also translated by him. 
All of the respondents have a high level of education, perhaps a peculiarity of the specific French-speaking community in Pretoria.

\section{Age distribution}

$\begin{array}{lllll}<21 & 21-25 & 26-30 & 31-35 & 36-40 \\ 26 \% & 11 \% & 26 \% & 16 \% & 16 \%\end{array}$

As far as the age distribution is concerned, it corresponds with the higher usage of the internet and social media among younger generations in South Africa. Karanja (2012) noted that in Africa the adoption of social media has been driven by a younger audience, with $60 \%$ of those participating in her research and posting messages in their twenties.

\section{Social media}

$\begin{array}{lllll}\begin{array}{l}\text { Respondents } \\ \text { using social } \\ \text { media }\end{array} & \begin{array}{l}\text { Respondents } \\ \text { using } \\ \text { Facebook }\end{array} & \begin{array}{l}\text { Respondents } \\ \text { using Twitter }\end{array} & \begin{array}{l}\text { Respondents } \\ \text { using MS } \\ \text { Messenger }\end{array} & \begin{array}{l}\text { Respondents } \\ \text { having access to } \\ \text { Internet using } \\ \text { social media }\end{array} \\ 81 \% & 77 \% & 27 \% & 18 \% & 95 \%\end{array}$

A very high percentage of the respondents who have access to the internet use social media, and this is also much higher than the use of social media among the wider South African population. Although the sample may be small, this indicates a significant variation - and much higher use of social media - than the broad South African population. Many of the respondents replied that they use social media to keep in contact with family and friends from the country of origin, which explains why these digital media are so popular in migrant communities. The pilot group seems to be part and parcel of the Google culture.

Respondents indicated that they use social media for the following (the responses have been clustered in themes):

(1) Relationships and community building

"To connect with friends", "to keep in touch with friends", "to keep in touch with friends and meet new people", "to communicate with my friends", "chatting", "to keep in touch with friends, family".

(2) Communication in the community and with family and friends from the country of origin

"To communicate with other Brothers and Sisters in the church", "to communicate and share the Word of God", "to communicate with my friends and family".

$86 \%$ indicated that they use social media to communicate with people from their country of origin, and $59 \%$ use it to communicate with people from South Africa. 
(3) News and information

"news", "Communication".

(4) Meeting new people

"Meeting new people".

(5) Share the gospel

$41 \%$ indicated that they use social networks to share the Word.

$68 \%$ thought that social media can play a role in the church, while $14 \%$ answered that they "do not know".

\section{Social media in church life}

It is perhaps more important to take notice of the reasons provided by the $68 \%$ who responded that social media can play a role in the church. The following reasons were given in the interviews (I have clustered the responses in themes):

(1) Communication and relationships

"It can play a role to communicate", "For evangelism, for keeping all the member in touch, for communication", "Spreading the Word of God, keeping in touch with churches".

(2) Proclamation and evangelisation

"In evangelisation", "to share the Word of God", "It's the quickest, cheapest to reach a vast number of people with the Word", "It can be used as a tool to preach the Gospel as a means to invite someone to church", "To bring people in church and save them from the world", "By exhorting and by sharing the word of God and also by making people aware of the world and what is happening", "By Sharing the Word of God", "For evangelism, for keeping all the members in touch, for communication", "By evangelism and exhort people to bring them back to Jesus and to show theme that there's no life without Jesus by the Word of God."

(3) Building up the community of faith

"The media play a big role in the church in our days to keep our faith in this life""Gospel and Life", "The Church can build the youth of today in teaching them through social media", "To Inspire".

(4) Information

"To Inform". 
These responses indicate the fact that these particular migrant communities are participating in the Google-culture in general, but the way in which they embraced new digital technologies and social networks in particular, indicates that they are already inculturating the gospel in the sense that the network society and technologies are part and parcel of their faith experience and utilised to facilitate relationships, share the gospel and support each other.

\section{Conclusion}

Migrant communities find themselves in the midst of the convergence of at least three significant present-day processes: (1) the rise of the network society, enhanced by digital social networks, (2) globalisation and (3) global migration. This convergence results in people not only migrating to new localities and territories, but simultaneously into a new culture - a change from a Gutenberg to a Google-culture. The challenge is to fruitfully integrate these processes into overall missiological reflection to incarnate the gospel in this emerging culture.

This paper described the missional challenge of this emerging culture in terms of the following:

- The rise of a hyper-social network society, a new Google culture.

- A proposal that contextualisation and inculturation in this culture can best be served by a theology of dialogue - an attitude of respect and friendship and a style of living in relationship with neighbors. It proceeds with the expectation of meeting God who has preceded us and has been relating to people - also in the globalised Google-culture. The foundational role of communication and relationships in both a network society as well as in migrant culture makes this dialogical approach to contextualisation and inculturation especially relevant.

- Contextualisation and inculturation, understood from a strong focus on diapraxis, recognise and build on the importance of relationships in migrant communities and embrace the opportunity presented by the relational nature of the network society.

- The growth in social media in the network society presents unique opportunities in this regard, because of the ability of social media to facilitate connection to, and create identity in, the multiple cultural and religious belongings of migrant communities.

- Hospitality has always been at the heart of Christian life. Social media present unique opportunities to facilitate new forms of hospitality to the stranger. 
A pilot study amongst French-speaking diaspora communities indicated that these challenges, as well as the proposal to approach contextualisation and inculturation from the perspective of a theology of dialogue, can indeed be very well addressed by social media. The respondents are participating in the growth of a network society and show significant usage of social media, especially Facebook. The use of Facebook and other social media plays a role in facilitating connection and the formation of identity in these communities, and the respondents clearly indicated that it plays an important role in church life and the inculturation of the gospel.

\section{References}

Archbishops' Council. 2004. Mission-shaped church. London: Church House Publishing.

Balia, D. and Kim, K. 2010. Witnessing to Christ today. Oxford: Regnum (Edinburgh 2010 Vol. II).

Bevans, S. and Schroeder, R.P. 2004. Constants in context. A theology of mission for today. New York: Orbis.

Bevans, S. and Schroeder, R.P. 2011. Prophetic dialogue. Reflections on Christian mission today. New York: Orbis.

Brown, M. 2011. Learn to use Facebook, Twitter, and LinkedIn: The How-To Guide. Kindle edn. Vook.

Bullas, J. 2011. 20 Stunning Social Media Statistics Plus Infographic viewed 14 June 2012 from http://www.jeffbullas.com/2011/09/02/20-stunning-social-media-statistics/.

Burger, C. 1995. Gemeentes in transito. Vernuwingsgeleenthede in 'n oorgangstyd. Lux Verbi: Kaapstad.

Castells, M., Fernandez-Ardevol, M., Qiu, J.L. and Sey, A. 2007. Mobile Communication and Society. A global perspective. Kindle edn. Cambridge, Massachusetts: MIT Press.

Chatterbox. 2012. Chatterbox digital social media statistics, viewed 18 June 2012 from http://www.youtube.com/watch?v=ixgE8Ay99eE\&feature=player_embedded \&noredirect $=1$

Challies, T. 2011. The next story. Life and faith after the digital explosion. Kindle edn. Grand Rapids: Zondervan.

Dingemans, G.D.J. 2005. De stem van de Roepende. Pneumatologie.Kampen: Kok.

Friedman, T.L. 2005. The world is flat. The globalised world in the twenty-first century. London: Penguin. (Updated and expanded edition).

Giddens, A. 2002. Runaway world. London: Profile Books.

Gottschall, J. 2012. The storytelling animal. How stories make us human. New York: Houghton Mifflin Harcourt.

Harr, E. 2012. Never been a better time to be alive, viewed 18 June 2012 from http://socialmediatoday.com/eric-harr-resonate-social-media/458294/never-beenbetter-time-be-alive. 
Hirsch, A. 2006. The forgotten ways. Reactivating the missional church. Grand Rapids: Brazos.

Johnson, T. M. and Ross, K.R. 2009. Atlas of global Christianity 1910-2010. Edinburg: Edinburgh University Press.

Kaplan, A. M. and Haenlein, M. 2010. Users of the world, unite! The challenges and opportunities of Social Media. Business Horizons 53(1): 59-68.

Karanje, B. 2012. How Africa tweets. Portland Quarterly, Issue 6,14 March 2012 viewed 10 July 2012 from http://www.portland-communications.com/how-africa-tweets.

Keifert, P.R. 1992. Welcoming the stranger. A public theology of worship and evangelism. Minneapolis: Fortress.

Kim, K. and Anderson, A. 2011. Mission today and tomorrow, Edinburgh 2010. Oxford: Regnum.

Koyama, K. 2010. Commission One after a Century of Christian Violence: The Search for a larger Christ, in Kerr, D.A. and Ross, K.R. (eds.). Edinburgh 2010: Mission then and now. Oxford: Regnum.

La Shure, C. 2005. What is Liminality? viewed 11 June 2012 from http://www.liminality.org/about/whatisliminality/.

McLuhan, M. 1962. The Gutenberg Galaxy. Toronto: University of Toronto Press.

Miller, R.M. 2004. The millennium matrix. Reclaiming the past, reframing the future of the church. San Francisco: Jossey-Bass.

Miranda-Feliciano, E. 2009. Christianity in cities, 1910-2010, in Johnson, T.M. and Ross, K.R. (eds.) Atlas of global Christianity 1910-2010. Edinburg: Edinburgh University Press: 240-241.

Netland H.A. 2006. Introduction: Globalization and theology today in Globalizing theology. Belief and practice in an era of World Christianity. Grand Rapids: Baker:14-36.

Oden A.G. 2008. God's welcome. Hospitality for a Gospel-hungry world. Cleveland: Pilgrim Press.

Pagitt, D. 2010. Church in the inventive age. Kindle edn. Minneapolis: Sparkhouse.

Penn, M.J. and Zalesne, E.K. 2007. Microtrends. The small forces behind today's big changes. London: Allen Lane.

Sweet, L. 2011. Real Church in a Social Network World: From Facebook to Face-to-Face Faith. Kindle edn. Colorado Springs: Waterbrook.

Sweet, L. 2012. Viral. How social networking is poised to ignite revival. Kindle edn. Colorado Springs: Waterbrook.

Tennent, T. 2010. Invitation to World Missions: A Trinitarian Missiology for the Twenty-first Century. Kindle edn. Grand Rapids: Kregel.

Turner, V. 1969. The Ritual Process: Structure and Anti-Structure. New York: Aldine de Gruyter. 
Shenk, W.R. 2006. Foreword in Globalizing theology. Belief and practice in an era of World Christianity. Grand Rapids: Baker:9-11.

Unchem, R. 2009. Theme statement on concepts and context of mission in Africa today. African Journal for Mission in Context (AMC)1(1), December, 2009:1-4.

Van Engen, C.E. 2006. The glocal church. Locality and Catholicity in a globalizing world, in Globalizing theology. Belief and practice in an era of World Christianity. Grand Rapids: Baker:157-179.

Walls, A.F. 2009. Christianity across twenty centuries, in Johnson, T.M. and Ross, K.R. (eds.) Atlas of global Christianity 1910-2010. Edinburg: Edinburgh University Press: 48-49.

Wheatly, M.J. 1999. Leadership and the New Science, San Francisco: Berret-Koehler. 